\title{
Distance Education and Human Resource Development: An empirical review
}

\author{
D. Ofosuhene
}

\section{ABSTRACT}

Distance education has been justified by many researchers to augment the development of human resources. This paper aimed to find out the extent to which distance education contributes to human resource development around the globe. The uniqueness of this study stem from its focus on bringing together on one platform differing empirical findings on distance education and human resource development. The study sought to synthesize the various studies focusing on the degree to which distance education influence human resource development. The rationale for this approach was to make it easier for decision makers and practitioners interested in such information to have unfettered access to varieties of opinion to inform strategic decision making. The paper explored empirical studies that have examined the relationship between distance education and human resource development. In all, 94 articles were consulted, however, 63 were analyzed qualitatively, using thematic analysis. These 63 articles were considered eligible based on their relevance to the study and for the fact that they were written in English Language. The review found the contribution of distance education to human resource development in areas of improved educational and professional capabilities of individuals, increased employability, income, standards of living and reduced marginalization. The review however, did not find any national policy framework geared towards the funding of distance education. The implication is that government and nations which have established distance education as an alternative mode of providing higher education should as a matter of importance focus on the establishment and implementation of national policies addressing issues of funding, technological innovation and the efficient running of distance education.

Keywords: Distance education, Education, Human Resource Development, Training and Development

Published Online: January 19, 2022

ISSN: $2736-5522$

DOI: $10.24018 /$ ejsocial.2022.2.1.178

\section{Ofosuhene}

University of Cape Coast

College of Distance Education

Cape Coast, Ghana.

(e-mail: dofosuhene@ucc.edu.gh)

\section{INTRODUCTION}

Globally, education has been found to be one of the key catalysts of growth and innovation, and the predominant factor contributing immensely to all facets of life. Education is considered the bedrock of economic and societal development. This realization has over the years motivated nations to enact laws and develop policies geared towards providing quality and affordable education for its citizens; with the goal of sowing the seed for sustained human development and economic growth. Over the last two decades, the demand for higher education around the world continue to grow mainly due to advancements in technology and the need to upgrade the capacities of human resource to equip them with evolving trends in new innovations. However, growing constraints of inadequate and poor physical facilities in the conventional system of education have made it impossible for many qualified applicants to access higher education. Consequently, this trend has resulted in the unpleasant situations of having qualified applicants being denied a chance to pursue higher education. This growing mismatch between the demand for higher education and the provision of physical educational infrastructure necessitated the need to provide an alternative mode of education that could provide equal access to all who qualify and are willing to pursue higher education. This condition, coupled with other factors such as geographical, economic, social and cultural constraints, brought about the introduction and justification of Distance Education.

Distance education, according to Moore and Kearsly (2011), is premised on the assumption that learning can be nurtured without the need for teachers and learners to be present at the same time and 
place. It is a system of education which allows learners to study in the 'comfort of their homes' (although some students meet on satellite campuses sometimes), via information communication technology and multi-media. This allows for a greater number of learners who are not physically present to have access to quality education. Many governments have planned and designed distance education to take care of the growing needs of human resources as well as developing those resources. This paper aims to find out the degree to which distance education augment human resource development. The uniqueness of this study, stem from its focus on bringing together on one platform differing empirical findings on distance education and human resource development. So far, a review of the extant literature suggests that almost all studies focusing on the topic exist as separate academic work with different or divergent conclusions. This study thus, seeks to synthesize or bring to one platform the various studies focusing on the degree to which distance education influences human resource development. The rationale for this approach is to make it easier for decision makers and practitioners interested in such information, to have unfettered access to varieties of opinions to inform strategic decision making. The rest of this paper follows this sequence: the second section focuses on an explanation of human resource development and a review of the extensive literature focusing on the link between distance education and human resource development. The third section concentrates on the methods and procedures used in filtering out the needed literature used in the extensive review of the linkage between distance education and human resource development. The final section centers on the findings and conclusions of this study.

\section{LITERATURE REVIEW}

\section{A. The Concept of Human Resource Development}

As found in the literature of Human Resource Development (HRD), a lot of confusion seems to surround the concept. Many authors have conceptualized human resource development in many different ways. For instance HRD has been conceptualized as training and education, career development, organisational planning and development and systematic development and performance of an organisation (Swanson \& Holton, 2008). In an attempt to explain human resource development, many researchers have argued the conceptual and theoretical perceptive of HRD, nonetheless, a distinctive conceptual and theoretical identity has not been established (Khan, Khan \& Khalid, 2012). Human Resource Development (HRD) is regarded as a process of developing human skills, competencies, knowledge and attitude for efficient production in national and organisational settings (Armstrong, 2010). It is regarded as a framework for the expansion of human capital within an organization through the development of both the organization and the individual to achieve performance improvement. Within a national context, it becomes a strategic approach to inter-sectoral linkages between health, education and employment. One of the earliest definitions of Human Resource Development was offered by Harbison (1973). He defined the concept as 'the process of increasing the knowledge, the skills, and the capacities of all the people in a society. In economic terms, it could be described as the accumulation of human capital and its effective investment in the development of an economy. In political terms, human resource development prepares people for adult participation in political processes, particularly as citizens in a democracy. From the social and cultural points of view, the development of human resources helps people to live fuller and richer lives, less bound by tradition. In short, the processes of human resource development 'unlock the door to modernization' (Haslinda, 2009).

Human resource development has also been defined as a comprehensive learning system for the release of the organisation's human potential, a system that includes both classroom and simulated learning experiences and experiential, on-the-job experiences that are necessary for the organisations' survival (McGuire, 2014). Swanson and Holton (2008) defined human resource development as organised activities arranged within an organisation to improve performance and personal growth for the purpose of improving job, the individual as well as the organisation. Human resource development has also been described as a set of systematic and planned activities designed by an organisation to provide its members with the necessary skills to meet current and future job demands (Werner \& DeSimone, 2012). These systematic and planned activities, according to Haslinda (2009), include training and development, career planning and development, performance appraisal and the management of change for organisational development.

The most widely acceptable definition of HRD, however, encompasses issues of training and development, health, nutrition, wellbeing of people, population, employment, science and technology, cognitive capacities, abilities and capabilities of people required to perform various functions within an organisation which is associated with current and future jobs, thereby ensuring personal growth, organisational sustainability and national development (Khan et al., 2012). The definition of HRD has been summarized as the process of developing and unleashing expertise for the purpose of improving individual, team and work process, and organisational system performance as well as national 
development. HRD activities also involve education and training that cover empowerment, awareness raising, skills enhancement, team building, community mobilization and development, organisational development, entrepreneurship development, sensitization and conscientisation, human resource planning and policies (Gibb, 2007).

The importance of human resource development has been outlined by many authors. For instance, Harbison, (1973) demonstrated that human resource development constitutes the ultimate basis for the wealth of nations. Capital and natural resources are passive factors of production; however, human beings are active agents who accumulates capital, exploit natural resources, build social, economic and political organisations and carry forward national development. Thus, economies that are unable to develop their human resources and effectively utilize them in the national economy might be constrained in their development efforts (Sharif, Ahmed \& Abdullah, 2013). Khan, Khan and Khalid (2012) suggested that the success or failure of any development project depends on the quality of human resources. The goal of human resource development encompasses national development and growth, organisational sustainability and competitiveness, and individual or personal growth and development.

Human resource development is seen as the improvement of knowledge, skills, health, education, capabilities and wellbeing of people (Ofosuhene, 2018). Developing human resource enhances economic growth through the production and provision of marketable good and services. Human resource development also affect the creation of surpluses needed to improve standards of living through increased income, more equitable distribution of income, increased employment opportunities, improved infrastructure and better social benefits (Khan, Khan \& Khalid, 2012). Human beings have some productive capabilities and skills that can be tapped into producing goods and services for national development (Teixeira, 2002). From the human capital theory point of view, these skills and capabilities are considered as assets because they influence organizational outcomes as well as the opportunity for people to earn higher wages, greater economic security and increase employment prospects (Armstrong, 2010).

\section{B. Elements of Human Resource Development}

As opined by Singh (2008), Human Resource Development is linked with the development of our personality, learning, satisfaction, happiness, love, freedom, truth, balance, fearlessness, wholesomeness and ease in a way which people can relate. In short, HRD relates to all aspects of development and progress of life. Sharif, Ahmed, \& Abdullah (2013) argued that HRD emphasizes the enhancement of human capabilities, which reflect the freedom to achieve different things that are considered valuable to people. Human resource development covers the integration of learning and development processes, operations and relationships. Its most powerful outcomes for the business are to do with enhanced organisational effectiveness and sustainability (Armstrong, 2010).

Human Resource Development has been described as a multi-dimensional concept because of the various facets of the disciple (Swanson \& Holton, 2008). Over the last two decades, discussions on HRD has centered on organisational development, training and development and career development and all of these components seek to address organisational growth issues. At the organizational level, a successful HRD programme prepares the individual to undertake a higher level of work, organized learning over a given period of time, to provide the possibility of performance change. HRD is the framework that focuses on organizations' competencies, training, and developing employee, through education, to satisfy the organizations long-term needs, the individuals' career goals and employee value to their present and future employers. Gibb (2007) established that HRD covers education, training and development, improving the cognitive capacities of people and enriching the capabilities of people in order for them to be proactive towards organisational and national goals. The OECD (2008) suggested that HRD encompasses educational attainment, health and population issues and a set of employment policies that provide business for workers with appropriate skills and abilities to adapt quickly to new challenges thereby fostering organisational growth and national development.

\section{Education}

Education is defined by Armstrong (2010) as the development of knowledge, values and understanding required in all aspects of life rather than knowledge and skill relating to particular areas of activity. Education is a system by which human capital of a nation is preserved and increased. From an economic point of view, higher standards in the schools are the equivalent of competitiveness internationally. Gibb (2007) posited that Education is an essential tool for human resource development because it has an impact on more than just economic growth, it also affect the development of individual and the larger society. Education is crucial to increase the productivity of people by providing them with skills they require to participate well in the economic and national development. Alam (2007) postulated that Education contributes to individual creativity, improves participation in the economic, social and cultural roles in society. Education also improves the understanding of an individual and their respect for others, thus promoting social cohesion and material understanding. Bloom (2006) believed that Education has an 
impact in the improvement of health and nutrition, technological development, democracy and equality. It also increases people's awareness of their environment, raises the productivity of workers and increases their earnings over their lifetime. Alam (2007) averred that Education does not only benefit those who gain it through increased income, but also helps in the overall societal development of a nation. The return on investment for the society will be a skilled workforce that will enable global competitiveness and economic growth. While the return for the individual will be an improved career path, increased earnings power and a better quality of life.

\section{Training and Development}

Armstrong (2010) identified that Training and Development (T \& D) represents the largest realm of HRD activities. Training and Development $(T \& D)$ provide opportunity for the expansion of human capabilities. Training is defined by Swanson and Holton (2008) as a planned and systematic modification of behaviour through learning events, programmes and instructions that enable individuals to achieve the level of knowledge, skill and competencies needed to carry out their work effectively. Development on the other hand is seen as the growth or realization of a person's ability or potential through the provision of leaning and educational experiences. Armstrong (2010) observed that Development is an unfolding process that enables people to progress from a present state of understanding and capability to a future state in which higher level skills, competences and knowledge are required. It is a form of learning activity that prepares people to exercise wider or increased responsibilities. Training and Development are very essential to increase the productivity of people by providing them with the requisite skills to increase organisational productivity and national development. Swanson and Holton (2008) viewed Training and Development as a process of systematically developing work-related knowledge and expertise in people for the purpose of improving performance.

\section{E. Capabilities}

Another element of human resource development, as noted by Gibb (2007), is the enhancement of human capabilities. To perform the standards expected in employment, individuals and organisations require more than certain levels of knowledge and understanding; they require capabilities. Capabilities are the practical skills or competence that people and organisation need to achieve the required performance. They are either inherent in a person or developed through practice. Capabilities are the sensible abilities involved in a work role. In order to effectively perform a job task, people require better understanding and knowledge as well as capabilities. Nussbaum (2000) identified capabilities as the freedom and ability to transform resources into valuable activities, the ability to live a life free from diseases, including physical and mental wellbeing.

\section{F. Cognitive Capacity}

Cognitive capacity is identified by Gibb (2007) as an important component of human resource development that needs to be discussed. Cognitive capacity relates to the development of knowledge and understanding. These are what people gain by learning for a work role, and what they get from experiences over time while in the role. Knowledge and understanding may be the 'know how' or 'know what'. Knowledge and understanding may be manifested in simple forms, such as making sense of a message or they may require the use of analytical and higher-order neurological abilities, demonstrated in actives such as problem-solving, decision making and creativity. Cognitive capacity involves perceptions and reasoning that is necessary to process information for the acquisition of knowledge. Gibb (2007) posited that cognitive capacity is an important component of human resource development for the purpose of effective performance of job task. Armstrong (2010) recognized that cognitive capacity is important for society as it assist in logic and reasoning, as well as memory and recall which are mandatory for successfully resolving societal and workplace issues. The way cognitive capacities are conceived reflects the way the brain is modeled. The brain involves basic parts like the cortex, which enables thinking, speech, motor control and spatial abilities. It is common to conceptualize the brain as having a division between areas specialized in processing logic, words, and numbers and areas specialized in processing rhythm, pictures and music. Some roles may require high levels of IQ or complex thinking skills. This is because some work is complex and requires the independent use of thinking and judgment. Other work role may require very little IQ or thinking skills. Such job roles may be fully scripted, with no requirement to do anything other than repeat a series of set behaviours or acts of communication.

Drawing from the Capability Approach by Sen (1995), Adorinoye and Ojokheta (2004) noted that development occurs when people have the ability to achieve what makes their lives valuable. These may include being literate, ability to make informed and meaningful live choices, having a sense of achievement and self-respect and having a better standard of living. The authors observed that for people to have the needed freedom and security to make meaningful life choices, they need education. Distance education is a sure way of providing society with the needed education since the conventional system of 
education have failed to provide equal access due to inadequate physical facilities. Adorinoye \& Ojokheta (2004) noted that the establishment of Distance Education has provided skill development, improved capabilities and competences of people which have improved their standards of living by making them employable, raising their income levels and helping them to enjoy their lives. Following consultation with extant literature, a qualitative survey with questionnaire, interviews and participatory experiences, Adorinoye \& Ojokheta (2004) found that Distance Education is the mechanism for Nigeria's sustained development and growth.

According to Obi (2013), Distance Education is seen as a mechanism for upgrading the knowledge, and attitude of people to improve work efficiency and productivity. The knowledge acquired through distance education also enable people to access jobs and get promotions in their workplaces, as well as meeting the needs of employers who are constantly demanding for skilled labour due to the changing global trends and the unstable macroeconomic conditions. The knowledge acquired equips people with problem-solving abilities, technical knowledge, managerial and entrepreneurial skills which are essential for individual freedom and self-sufficiency. Obi suggested that distance education can help increase employability of many people in Nigeria. Ojokheta and Aderinoye (2004) attested that distance education has helped in producing efficient skilled workers for better output, growth and national development. The researchers claimed that distance education has trained a number of people who are capable of managing their own enterprises in Nigeria. Commenting on the advantages of distance education to human resource development, Ojokheta and Adrinoye (2004) affirmed that the introduction of distance education in Nigeria has enabled many subsistence farmers, village women, community leaders and adults gain valuable education, expertise and knowledge which they apply in the transformation of their local communities. This has subsequently increased their standards of living and raised their level of income.

As opined by Robinson (2008), China has been able to improve the development of its rural professional teachers as well as increased school enrolment due to the establishment of distance education in the country. This has contributed significantly to the quality of teaching and learning and the development of these professional teachers. Robinson alluded that the Chinese government has used distance education in ensuring equity and for the achievement of development goals, which has helped to reduce rural poverty in the poorest 41 provinces in the Gausu Counties. He observed that teacher quality has been raised, their ideas have changed so much, their teaching skills have improved, they have good command of new teaching and their vision has widened.

In an Iranian study, the researchers found that distance education is the most efficient and costeffective way of developing a country's human resources. Using structural equation modeling, Najafi et al. (2014) established that if distance education is implemented correctly, it can help to improve human resource development through the enhancement of knowledge, skills and attitude of individual in Iran. In a similar study in Malawi, Chawinga and Zozie (2016) reported that distance education has been a tool to widen access to higher education, as more and more Malawians were not able to access higher education due to limited physical facilities in the conventional system of education. The establishment of distance education in Malawi has assisted in the enhancement of human resource development. In Ethiopia, for instance, Mohammed and Teshome (2012) examined the prospects of Distance Education in developing the nation's human resources. Their study established that distance education does not only improve the individual's standard of living, but also provides the type of skills and competencies necessary for industrial as well as economic development. At the individual level, the researchers observed that the knowledge and skills obtained through distance education increased productivity, improved health and sanitation, bridged the gap of inequality, and improved the living standards of women in particular.

Olakuhein (2006) emphasized that distance education was the major strategy for empowering women in Africa, as more and more women were taking advantage of the opportunities of distance education. This enables them to make life informed choices that affect their lives and their families as well. Mohammed and Teshome (2012) discovered that 45\% of Namibian population had studied through Distance Education; of this figure, $70 \%$ are females. Thus, Distance Education is bridging the gap and ensuring equity as more and more females are getting the requisite knowledge, skills and capabilities to be employable and earn higher wages just like their male counterparts. In Ghana, Mensah and OwusuMensah (2002) pointed that many qualified learners were turned away from pursuing higher education due to inadequate physical facilities at the convention system of education. This was so alarming that there was the need for an alternative mode of education which allowed qualified learners to pursue higher education. By 2015, more than thirty thousand Ghanaians from the educational, the public and commercial sectors have been trained in various fields of study through distance education (Ofosuhene, 2018). This expansion has contributed significantly to the development of human resources in Ghana. It is reported that more and more women who are married and could not leave their families for higher education are taking advantage of distance education and educating and building their careers.

In the perspective of Kwapong (2007) women are constrained by some variables such as time, space, resources and socio-economic disabilities, which hinder them from pursuing higher education. Distance 
education is seen as an avenue for overcoming these barriers by enabling women to learn at their own pace and take up vocations and skills for economic and individual development. Distance education provides opportunity for women to step up into the main system of education, including higher education, thus enabling them to earn higher wages and improve their standards of living. Lama and Kashyap (2012) acknowledged that the conventional system of education in India has failed to provide the needed education to the citizens. This event according to the researchers significantly affected the employability of the people. This was attributed to the lack of access to higher education. With the establishment of distance education in India, the authors observed there has been variety of programmes that have enabled learners to be employed in the field of their choices, thus increasing their employability. This has contributed to the production process which has translated into economic and national development.

In Tanzania, Nartker et al. (2010) collected data from 25 distance education institutes focusing on health to find out how distance education impact the experiences of health workers. The authors employed survey, interviews and on-site observation and found that health workers use distance education to professionally upgrade themselves. The researchers opined that distance education is the most effective method to increase motivation, knowledge and skills. This led to an upward surge in the professional capabilities of a number of health care workers to care for the Tanzanian population. The researchers concluded that distance education has achieved significant success and has contributed positively in reducing the country's shortage of health care workers.

Drawing from previous empirical studies, a Turkish study provided evidence that distance education has significantly increased economic and social gains (Kilinc, Yazici, Gunsoy \& Gunsoy, 2016). The study found that distance education has bridged the gap of income inequality between males and females, due to increased access of education, employability and higher wages for women. For instance, in China, Hong Kong, India, Pakistan, Sri Lanka and Bangladesh, distance education had positive effect on women and children. Women are able to access and benefit from microfinance for the establishment and expansion of businesses (Kanwar \& Tapin, 2001). This development has increased the level of income of these women and has improved their living standards as well. In a correlational analysis, Ofoegbu (2009) noted that distance education significantly and positively relates to human resource development, through increased income, human security, better standard of living and sustained growth. Moreover, Ferdousi (2010) ascertained that distance education has significantly reduced poverty, conflict and marginalization and improved human development.

\section{RESEARCH METHODOLOGY}

This study explored the empirical studies that have examined the relationship between distance education and human resource development around the globe. The researcher sought different publishing houses for this study, leading to the discovery of body of literature that is published in Distance and Open Learning as well as Human Resource Development Journals, though these were fragmented and disjointed in nature. Searches of the electronic databases included Google Search, Google Scholar, Emerald insight, Sage Premier Journals, Science Direct, Taylor and Francis Online and Wiley and Sons. The search for articles were done using terms like 'distance education and human resource development', 'online distance learning and human resource development', 'open learning and human resource development' and 'web-based learning and human resource development'. Other sources for additional papers were references within key articles. These sources were considered credible as they were published from reputable and credible journals which screen and peer reviewed these articles before publishing them. After the search, the author identified and selected articles relevant for the review.

A second reviewer evaluated the articles independently to minimize biases. Articles selected were considered eligible for inclusion based on their relevance to the topic under study and for the fact that they were written in English Language. The first stage in the screening process involved the screening of titles, abstracts, introductions and conclusions of these articles. In all 94 articles were consulted, however, 63 were considered eligible for inclusion in the study. The 63 studies that were analysed were published and made available between 2000 and 2018. These include conference proceedings and journals with varying degree of impact which were published in Open, Online and Distance Learning as well as Human Resource Development researched in different countries. Many of these papers have been published in Africa, Asia and the Sub-Sahara, with majority of the research conducted in Nigeria. The analysis of data was done qualitatively using thematic analysis.

\section{FINDINGS}

A noticeable feature of the studies reviewed was the contribution of distance education in the professional development of teachers and as a strategy for empowering women. Generally, researchers 
have referred to terms like Online, Open Learning, Distance Learning, E-Learning, and Continuous Education. The term 'Online and Open Learning' were frequently used in place of Distance Education. Many of these research studies have been conducted in Nigeria and India. The role of Distance Education in developing human resources is seen in areas of balancing inequalities between age groups, extending geographical access to education, providing education for a larger audience, providing education for otherwise neglected population, expanding the capacity for education in new multidisciplinary subject area and developing competencies through continuous education. Distance Education has made possible and has overcome the problem of geographical distance, personal constraints, cultural and social barriers and lack of physical educational infrastructure. It is also regarded as a cost-effective means of pursuing tertiary education. The concept also offers flexibility to student-workers to be able to combine studies with work schedule. The review found that Distance Education is mostly used to train teachers and health workers. The concept is used to reduce marginalization in most communities especially amongst women, giving them the opportunity to increase their values as well as increase their personal income.

The current literature agrees that distance education plays a crucial role in the development of human resources and national development, however, the study found very little in areas of national policy framework geared towards distance education. For instance, in the Ministry of Education Expenditure Framework in Ghana (2017-2019), there was no mention of any budget allocation to Distance Education. Many researchers and intellectuals have advocated for the implementation of strategic planning and national policies on Distance Education, however, apart from South Africa and other few countries, many countries especially in Africa lack policy framework on Distance Education.

Moreover, some challenges associated with distance education were also identified in the review. For instance, Heydenruch (2015) noted that increasing number of students who enroll for distance education are not academically experienced to be left to study independently as required by the operations of distance education. This has resulted in most students not being successful in pursuit of academic excellence. Further, the researcher noted that distance education becomes a 'second choice' for disadvantage students who are from non-performing schools and see distance education as an option for last resort and not of choice. This phenomenon accounts for a higher failure rates of distance education students. Additionally, Ahmed and Yeasmin (2010) observed that Distance Education in some countries operates within the framework of the conventional system of education. The changeover from the 'brick and mortar' to virtual and technologically based learning has not been assimilated by many academicians within the conventional university. This poses great challenge as most academics do not appreciate the Distance Education system and its full implementation. In terms of costs, Obioha and Ndidi (2011) identified that the cost of installing, maintaining, using and upgrading technology to support Distance Education is very expensive, especially in the area of telecommunication and internet connectivity in most parts of Africa.

\section{CONCLUSION}

The study aimed at finding the extent to which distance education contributes to human resource development as presented by various studies from different geographical perspectives. It is an undisputed fact per this study's review that distance education has contributed enormously to the development of human resources across the globe, in spite of the challenges identified by the review. Review of literature found that such development has been in areas of increased education, capabilities, employability and income, thus improving the standard of living of people. It was also noted that distance education has reduced marginalization and bridged the gap of inequality between males and females. However, in spite of the contribution of distance education towards the development of human resources, the study did not find concrete national policy implementation geared towards the funding of distance education, apart from South Africa and other few countries. The implication is that government and nations which have embraced distance education as an alternative mode of providing higher education should, as a matter of importance, focus on the establishment and implementation of national policies addressing issues of funding, technological innovation and the efficient running of distance education.

\section{FUNDING}

This paper was not funded by any organised body 


\section{REFERENCES}

Abimbola, E. A., Williams-Oladapo, O. O. \& Tijani, F. Y. (2015). Assessing the impact of open and distance learning in enhancing the status of women in Lagos State. Procedia-Social and Behaviour Sciences, 174, 1512-1520.

Aderinoye, R., \& Ojokheta, K. (2004). Open-Distance Education as a Mechanism for Sustained Development. Reflections on the Nigerian experience. International Review of Research in Open and Distance Learning, 5(1), 1-13.

Ahmed, M., \& Yeasmin, S. (2010). Quality Assurance and Distance Education System: Problems and Challenges. International Journal on New Trends in Education and their Implication, 1(2), 23-32.

Alam, G. M. (2007). Private HE in Bangladesh: the impact on HE governance \& legislation. Unpublished PhD Thesis, University of Nottingham, United Kingdom.

Armstrong, M. (2010). A Handbook of Human Resource Management Practice (10 ${ }^{\text {th }}$ Ed.). London: Kogan Page Ltd.

Bloom, D. E. (2006).Measuring Global Educational Progress. In Educating All Children: A Global Agenda, ed. Joel E. Cohen, David E. Bloom, and Martin B. Malin. Cambridge, MA: The MIT Press.

Chawanga, W. D., \& Zozie, P. A. (2016). Increasing Access to Higher Education through Open and Distance Learning. Empirical findings from Mzuzu University, Malawi. International Review of Research in Open and Distance Learning, 17(14), 1-20.

Dreze, J., \& Sen, A. (1995). India Economic Development and Social Opportunity. Delhi, India: Oxford University Press.

Ferdousi, N. (2010). Distance education for law promotes gender equity in Bangladesh. Asian Journal of Distance Education,8(1), $81-86$.

Gaba, A. (2008). Distance education and human resource development. The Indian open learning journal, 8(5), $233-239$.

Gibb, S. (2007). Human Resource Development: Processes, Practices and Perspectives at Work. Basingstoke: Palgrave Macmillan.

Harbison, F. H. (1973). Human Resources as the Wealth of Nations. New York: Oxford University Press.

Haslinda, A. (2009). Evolving terms of Human Resource Management and Development. The Journal of International Social Research, 2 (9), 180-186.

Heydenrych, J. (2015). Education (Im)Possible: Reconsidering the Contribution of Distance Education in South Africa. Asian Journal of Humanities and Social Sciences, 3(2), 1-18.

Kanwar, A. S., \& Tapin, M. (2001). Brave New Women of Asia: How Distance Education Changed their Lives. Canada: The Commonwealth of Learning.

Khan, M. T., Khan, N. A., \& Khalid, M. K. (2012). An Organisational Concept of Human Resource Development - How Human Resource Management Scholars view HRD (Literature Review). Universal Journal of Management and Social Sciences, 2(5), 36-47.

Killinc, B. K., Yazici, B., Gunsoy, B., \& Gunsoy, G. (2016). A qualitative statistical analysis of the performance of open and distance learning: a case study in Turkey. Journal of Scientific Research and Development 3(7), 86-90.

Kwapong, O. A. T. F. (2007). Widening Access to Tertiary Education for Women in Ghana through Distance Education. Turkish Online Journal of Distance Education, 8(4), 65-79.

Lama, S., \& Kashyap, M. (2012). Empowering the Human Resources and the role of Distance Learning. Turkish Journal of Distance Education, 13(3), 239-246.

McGuire, D. (2014) Human Resource Development: theory and practice, (2 $2^{\text {nd }} \mathrm{ed}$.). London: Sage Publications.

Mensah, S. K. E., \& Owusu-Mensah, F. (2002). Priorities and Strategies for capacity building in Tertiary Distance Education for HRD in Ghana. A final report prepared for the World Bank.

Mohammed, T., \& Teshome, T. (2012). Distance Education as a Tool for Development: The Prospect of Private Distance Education in Ethiopia. Proceedings of the $10^{\text {th }}$ International Conference on Private Higher Education in Africa, Addis Ababa. Aug. 8-10.

Moore, G. M., \& Kearsly, G. (2011). Distance education: A systems view of online learning. Belmont, CA: Wadsworth Publishing.

Najifi, H., Rezaei, M. J., Rasulazadeh, B., \& Heidari, M. H. (2014). Identification of the components of Open and Distance Education and Human Resource Development in Iranian Universities. Journal of Education and Practice, 5(17), 91-96.

Nartker, A. J., Stevens. L., Shumays. A., Kalowela, M., Kisimbo D, Potter K (2012). Increasing health worker capacity through distance learning: a comprehensive review of programmes in Tanzania. Human Resource for Health 8(30).

Obi, R. O. (2013). The role of Distance Education in the Human Resource Development of Nigeria. International Journal of Research Development, 2-7.

Obioha, M. F., \& Ndidi, U. B. (2011). Administrative Problems and Open Distance Education in Nigeria. A Case Study of National Open University of Nigeria. Journal of Educational and Social Research, 1(5), 88-97.

Ofoegbu, I. F. (2009). Female access to basic education: a case for open distance learning (ODL). Edo Journal of Counselling, 2(1), 46-57.

Ofosuhene, D. (2018). Job Stress and Human Resource Development at the College of Distance Education, University of Cape Coast, Ghana. Doctoral Thesis, University of Cape Coast.

Olakulehin, F. K. (2006). Distance Education as a Women Empowerment Strategy in Africa. Turkish Online Journal of Distance Education, 7(1), 149-154

Omolewa, M. (2008). Rethinking Open and Distance Learning for Development in Africa. Proceedings of the 2nd Africa Council for Distance Education (ACDE) conference and General Assembly, 1-6.

Organisation for Economic Cooperation and Development (2008). Tertiary Education for the Knowledge Society, 1, $49-54$.

Robinson, B. (2008). Using Distance Education and ICT to improve access, equity and quality in rural teachers' professional development in Western China. International Review in Open Learning, 9(1), 1-17.

Singh, S. K. (2008). Human Resource Development: HRD-IR Interface Approach. New Delhi: Atlantic Publishers.

Swanson, R. A., \& Holton, E. F. (2008).Foundations of Human Resource Development (1 ${ }^{\text {st }}$ ed.). San Francisco: Berrett-Koehler Publishers, Inc.

Werner, J. M., \& DeSimone, R. L. (2012). Human Resource Development (6 ${ }^{\text {th }}$ International Ed.), South-Western: Cengage Learning. 